УДК 342.5-043.86 (477) (091) «08/11»

DOI https://doi.org/10.32837/apdp.v0i88.3055

B. О. Карпічков

\title{
СТАНОВЛЕННЯ ТА РОЗВИТОК ОРГАНІВ МІСЦЕВОЇ ВЛАДИ В ДАВНЬОРУСЬКІЙ ДЕРЖАВІ
}

Становлення органів місцевої влади на українських землях здавна викликало інтерес вітчизняної історико-правової науки та науки адміністративного права. Однак, на жаль, більшість наявних наукових праць, присвячених дослідженню місцевої влади в Давньоруській державі, лише частково проливають світло на іï особливості, що породжує невизначеність і низку суперечностей. Окрім того, багато питань потребують сучасного переосмислення й узагальнення. Деякі сучасні науковці вважають, що система органів місцевої влади на давньоруських землях була досить примітивною, однак, на наше переконання, апарат місцевого управління Русі, незважаючи на простоту, відзначався своєю дієвістю, розвивався та вдосконалювався відповідно до реалій того часу.

Метою статті є комплексний історико-правовий аналіз органів місцевої влади в Давньоруській державі з кінця IX до XIII ст., їхньої структури, особливостей і місця в системі адміністративного апарату на основі систематизації й узагальнення інформації з історичних джерел, пам'яток права, історико-правових досліджень українських і російських учених.

Окремим питанням місцевої влади в Давньоруській державі присвячені праці відомих українських учених М.С. Грушевського [1; 2], Д.І. Дорошенка, Н.Д. Полонська-Василенко, М.Ф. Котляра [3; 4; 5], В.М. Рички [4; 6], П.П. Толочка $[7 ; 8 ; 9]$, Н.Н. Яковенко, С.В. Кульчицького, Ю.І. Терещенка [10], С.В. Юшкова [11; 12; 13], а також праці російських науковців І.Д. Бєляева [14], М.Ф. Владимирського-Буданова [15], М.Д. Затиркевича [16], М.Б. Свердлова [17; 18], В.І. Сергєєвича [19], О.Є. Прєснякова [20], В.Й. Ключевського [21], Б.О. Рибакова, І.Я. Фроянова [22], Л.В. Черепніна, М.М. Карамзіна [23], Б.Д. Грекова й інших дослідників.

Важливу інформаційну цінність для нашого дослідження становлять такі історичні джерела, як літопис «Повість временних літ» [24; 25], збірник норм давньоруського права «Руська правда» [26], твори XI-XIII ст. «Слово о полку Ігоревім», «Повчання Володимира Мономаха» [27] тощо.

Еволюція органів місцевої влади в Давньоруській державі напряму залежала від процесу становлення державності, а також низки інших чинників, що неминуче вплинули на їх становлення та розвиток. Передусім ідеться про особливості системи державного управління, адміністративно-територіальний поділ земель, ступінь централізації влади, поширення християнства, розвиток князівського, боярського і церковного землеволодіння.

Модель державно-адміністративного управління на Русі, хоча й була схожа на західноєвропейську модель того часу, проте все ж таки мала свої особливості. Як нам відомо, наприкінці IX-X ст. на Русі існувала так звана десяткова (чисельна, 
або земська) система державного управління. Ця модель є найдавнішою, а її походження явно додержавне, цілком імовірно, що вона існувала ще за часів великого переселення народів [28, с. 75-77]. Більшість народів світу в певний період їхнього розвитку в поділі війська використовували саме таку систему, тому першочергово десяткова система застосовувалась в організації князівських військ, дружин. Згодом, коли військові походи зменшились, десяткова система перетворилася на адміністративно-територіальну систему управління державою, а командувачі військових гарнізонів стали місцевими управителями. Характерною особливістю десяткової система було те, що вона не відокремлювала центральне управління від місцевого, тому досить тривалий час у Давньоруській державі не існувало чітко визначених органів місцевої влади і конкретного розподілу владних повноважень між посадовцями, компетенція яких часто дублювалась, що інколи навіть спричиняло конкуренцію між ними.

За десяткової системи управління органи місцевої влади формувались переважно із числа князівських дружинників і нащадків родоплемінної знаті. Владу в містах тоді здійснювали воєводи військових гарнізонів - тисяцькі, соцькі, десяцькі, а також виборні посадові особи - старці (старости) у селах. Великий князь Київський призначав посадовців із кола найбільш відданих йому людей, якими зазвичай були командувачі окремих підрозділів князівської дружини. Так, у центрах на завойованих і приєднаних до Києва землях київські князі ставили гарнізони дружини [29 с. 54]. Тисяцький був начальником найбільшого військового гарнізону (тисячі), який зазвичай ставили у великих містах-центрах або ж у стратегічно важливих землях, а соцькі командували окремими його частинами (сотнями). У невеликих містах ставили менший гарнізон під керівництвом соцького, а окремими його частинами там командували десяцькі. Отже, тисяча стала великим територіальним округом (землею-князівством), підпорядкованим тисяцькому, який був управителем найбільшого міста-центру землі, командувачем його ополчення та воєначальником збройних сил усього округу. У підпорядкуванні в тисяцьких перебували нижчі за рангом посадові особи соцькі та десяцькі. Окремі адміністративні одиниці (громади) у містах і приміських зонах (сотні) підпорядковувались соцьким, десяцькі, імовірно, здійснювали управління в маленьких містечках.

Функції воєвод тисяцьких, соцьких і десяцьких були схожими, однак відрізнялись одна від одної залежно від обсягу їхньої влади. 3 посиленням централізації та збільшенням залежності земель-князівств від центру (Києва) обсяг їхніх повноважень змінився. 3 X-XI ст. тисяцькі та соцькі стали здійснювати військову, адміністративну, господарську, фіскальну, судову і поліцейську владу [11, с. 53], стежили за правопорядком у містах і околицях міст, допомагали князівським збирачам данини (у разі потреби надавали їм військову підтримку), придушували повстання, стежили за проведенням торгів, а також виконували окремі судові функції та доручення великого князя [29, с. 55]. Пізніше, з розвитком інституту посадництва, вони набули галузевої спеціалізації: тисяцькі стали головними помічниками князів у містах, де здійснювали управління і командували військом, а соцькі стали виконавцями судово-адміністративної влади. Варто зазначити, що тисяцький 
також представляв інтереси міської громади у відносинах із великим князем. Становище воєводи тисяцького за впливовістю було наближене до князя, адже тільки в підпорядкуванні останнього могло бути таке велике військо. Тисяцький також заміщав князя в управлінні містом на час його відсутності, командував дружиною, разом із князем брав участь в ухваленні нових законів, за якими жила місцева громада, мав право суду в деяких справах, а також виконував різноманітні представницькі функції. Іноді авторитет тисяцьких був настільки великий, що вони могли залишатися на своїх посадах навіть коли князь змінювався [30, с. 63]. Усі представники князівської влади на місцях утримувались коштом місцевого населення.

Характерною особливістю місцевого самоврядування в Давньоруській державі є його общинний територіально-виробничий характер. Оскільки суспільство того часу не знало чітких класових поділів, більшість населення становили особисто вільні люди, які об'єднувалися в сусідські територіальні громади. Сусідські громади міст і сіл утворилися внаслідок поступової заміни родового ладу на общинний [14, с. 25], але такі громади були основою організації давньоруського суспільства ще з давніх часів не лише через кровну спорідненість, але й через розподіл праці, а також необхідність об'єднання сусідів для захисту від спільного ворога. Згодом такі сусідські громади почали об'єднуватися у племена, а ті в союзи племен, центрами яких стали укріплені міста. Отже, ще до X ст. на просторах давньоруських земель існували численні вільні громади міст і сіл, які користувалися чималою автономією у вирішенні своїх господарських і адміністративних питань. Головним органом влади територіальних громад у містах і селах були народні збори (віче), у яких брали участь голови родів і старійшини. Віче збиралось за потреби, а до його компетенції належав розгляд питань про перерозподіл земель, охорону святилищ, вирішення спорів між окремими родами та громадами, винесення вироків за тяжкими злочинами, їх публічне виконання, ухвалення рішення щодо переселення в інші землі, питання оборони від ворогів тощо. Усі рішення на віче ухвалювались шляхом звичайного консенсусу між його учасниками [31, с. 38-39]. У буденний час більшість справ громади вирішували голови родів і осель - старці (старости) $[19$, с. 23$]$, які обирались на віче, де також визначався обсяг їхньої влади. Зазвичай старці здійснювали управління громадою, організовували господарські роботи, представляли інтереси громади у відносинах з великим князем і його посадовцями, скликалитапроводиливіче, організовуваливиконаннярішень, ухваленихнавічетощо.

Цікавим є те, що в деяких землях-князівствах (наприклад, у Новгороді) десяткова модель управління майже не зазнавала істотних змін із моменту її виникнення [20, с. 188].

Унаслідок адміністративних реформ київських князів у Х ст. поділ держави на військово-територіальні одиниці (тисячі та сотні) змінився адміністративно-територіальним, за яким уся територія держави стала поділятись на землі-князівства, а ті - на волості. Більшість давньоруських земель тоді були поділені між синами великого князя, які сіли на трон у великих містах-центрах, а в інших містах управління здійснювали його посадники (князівські мужі, місцеві князі та князі-вожді), волостелі у волостях, тіуни в погостах, воєводи тисяцькі та соцькі продовжували виконувати свої управлінські функції в містах, а старости - у селах. 
Інститут посадництва (намісництва) виник на Русі в результаті реформ Володимира Великого у Х ст. На той час усі державні землі були залежними від центру - Києва, сплачували данину Київському князю, а владу в містах і прилеглих до них околицях здійснювали посадники. Зазвичай посадники обиралися великим князем із його синів, родичів, дружинників і «добрих мужів». Посадники здійснювали управління в найбільших містах за винятком тих, де проживав великий князь (винятком став лише Новгород) [32, с. 261]. Посадник здійснював у місті й околицях вищу адміністративну, поліцейську і судову владу, стягував на користь Київського князя судові штрафи, здійснював контроль за збором уроків і данини, стежив за проведенням торгів, мав власну дружину, а також командував міським ополченням $[18$, с. $219 ; 33]$. Частину зібраної данини посадник міг залишити собі, оскільки утримувався коштом місцевого населення. На перший погляд може здатися, що посадник мав приблизно той же обсяг влади, що і сам великий князь, але посадник не був володарем, він був лише представником князя, його слугою [16, с. 107, 182-183]. Цікавим є те, що в Новгороді у XII ст. посадник уважався вищою посадовою особою й обирався міським віче, яке його призначало, а за потреби заміщувало. Він був головою державної адміністрації, командував військом, контролював князя у здійсненні ним влади, очолював військовий суд, вів дипломатичні переговори, укладав союзи, оголошував війну тощо. Однак у Новгороді князь усе одно стояв вище за посадника [34, с. 382-384; 35, с. 434-520].

Служба посадника також передбачала низку обмежень. Так, посадник не мав права власності на землю, а лише використовував її на час здійснення служби, він не міг втручатися у внутрішні справи громад міста, оскільки ті мали власні органи самоврядування (віче, тисяцьких, соцьких і старост). Коли великий князь прибував у місто, яким управляв посадник, то влада останнього тимчасово призупинялася та переходила до князя [16, с. 182-183]. 3 посадниками, які чинили свавілля чи зловживали владою, міська громада могла суворо розправитися.

Варто зазначити, що посадництво як різновид управлінської діяльності не було однорідне, як нам відомо, одними містами великий князь управляв через своїх синів, а в інших - через мужів [23, с. 156]. Тому можна виокремити посадництво князівських синів і мужів. Посадництво князівських синів виникло за князя Святослава, коли той посадив своїх синів князювати в інших землях (Ярополка в Києві, Олега у древлян, а Володимира в Новгороді) [25; 27]. Князівські сини як посадники були більш самостійними, ніж посадники-мужі, оскільки через родове становище вони були не як підлеглі чи слуги великого князя, а ніби його сини. Була досить поширена практика, коли князі відправляли своїх синів князювати в інші землі для того, щоб ті набрались управлінського досвіду та були готові (за потреби) посісти трон замість свого батька. Старших синів зазвичай відправляли князювати в більш стратегічно важливі землі. Також траплялося, що князі «пересували» синів між різними землями, щоб ті подовгу не затримувалися на одному місці і не укріпили там свою владу, тим самим не загрожували владі їхнього батька. Часто посадництво для синів князя було лише тимчасовим явищем, оскільки вони мріяли або про київський трон, або ж про незалежність своїх князівств від Києва. Коли великий князь помирав, посадництво його синів 
припинялося, вони саджали власних посадників у важливих містах, щоб відбити своїх конкурентів - братів, зайняти батьківський трон [36, с 10.]. Великі князі надавали своїм синам земельні наділи разом із містами і селами у спадкове володіння. Як наслідок, на території Давньоруської держави з'явилось багато удільних князів із роду Рюриковичів, які, у свою чергу, створювали власні князівські династії та намагались здобути автономію від Києва.

Посадництво мужів виникло раніше за посадництво князівських синів, так, ще наприкінці IX ст. князь Олег, захопивши Смоленськ і Любеч, посадив там своїх мужів [25, 9 зв.]. Посадники-мужі призначалися великим князем зі знатних дружинників і бояр та були більш залежними від нього, бо князь у будь-який момент міг припинити їхні повноваження. Цей різновид посадництва був поширений переважно в менших містах. Деякі посадники-мужі навіть могли служити князівській династії протягом кількох поколінь [36, с. 11-12].

Окрім князівських синів і мужів, посадниками могли також бути місцеві князі та князі-вожді. Під час військових дій або князівських міжусобиць у завойованому місті для тимчасового управління київські князі спершу ставили посадниками своїх мужів, а коли обстановка ставала більш-менш стабільною, то замість них робили посадниками місцевих князів [25, 93 зв.], які не належали до династії Рюриковичів. Місцеві князі здійснювали владу паралельно із владою великого князя і формували власні органи місцеві влади. На відміну від попередніх різновидів посадництва, між Київським князем і місцевими князями існували відносини васалітету-сюзеренітету, які скріплювались хрестоцілувальними грамотами. Оскільки місцеві князі одержували землю безпосередньо від великого князя, то вони зобов'язувались йому служити. До основних їхніх зобов'язань належали: сплата частини данини, зібраної з підвладної їм землі, на користь великого князя, надання, у разі потреби, військової підтримки сюзерену і розміщення його військ на своїх землях. Щоправда, місцеві князі не мали великих ополчень і могли відіслати на допомогу великому князю тільки якусь частину війська. Місцеві князі самостійно управляли своїми землями, мали власні дружини, ухвалювали місцеві закони, налагоджували дипломатичні відносини з іншими князівствами та державами. Цікавим є те, що інколи місцеві князі теж називали себе «великими», щоб підкреслити свій статус управителів, хоча і місцевого рівня. У XI-XII ст. внаслідок постійних князівських міжусобиць місцеві князі зміцнили свій військово-адміністративний апарат, а їхні землі-князівства перетворились на самостійні утворення у складі Давньоруської держави.

Незважаючи на спроби київських князів викорінити племінне князювання, до середини X ст. на давньоруських землях продовжували існувати численні племінні князівства, що сформувались унаслідок об'єднання племен і будувалась на інституті родової спорідненості та військової демократії [37, с. 99]. Із часом більшість таких князівств прийняли сторону великого князя. Племінні князівства за традицією очолювали князі-вожді, яким належала вся влада у воєнний час, але в мирний час їхня влада обмежувалась народними зборами (віче), у яких брали участь усі дорослі чоловіки племені, що могли тримати у своїх руках зброю. За давньоруськими традиціями на віче вирішувались найважливіші адміністративні, 
господарські та політичні питання. Також існувала рада старійшин, що відігравала роль дорадчого органу при вожді. Діяльність князів-вождів спрямовували родоплемінна знать і військова дружина [20, с. $25 ; 38$, с. 36]. Відносини великого князя і князів-вождів мали деякі особливості, оскільки останні, на відміну від місцевих князів-намісників, не виконували класичні для того часу феодальні повинності. Князі-вожді продовжували володарювати на своїх землях, однак дозволяли Київському князю збирати з них данину (щоправда, інколи не без опору). Цікавим є те, що князі-вожді не відбували обов'язкової для васалів великого князя військової повинності, але цілком ймовірно, що вони могли брати добровільну участь у його військових походах.

Із другої половини XII ст. посадництво поступово зникає, поступаючись місцевим (удільним) князям [21, с. 180-181]. Із часом інститут посадництва перетворився на місцевий аналог вотчинної системи управління [13, с. 79], посадництво стало спадковим, а самі посадники стали типовими феодалами [11, с. 190].

Волостелі (старости) були вищими представниками давньоруської обласної адміністрації та здійснювали управління у волостях - невеликих, чітко не встановлених адміністративно-територіальних одиницях сільської місцевості. Призначався волостель великим князем із дружинників, бояр, боярських дітей, сільських старост, а також зі службовців нижчого рангу та нетитулованих осіб [15, с. 75-77]. Волості, як і міста, становили окремі одиниці землі-князівства, що не залежали одна від одної. За аналогією до служби посадника в місті, волостель представляв владу великого князя в сільській місцевості та виконував для цього адміністративно-управлінські, господарські, поліцейські, військові та фіскальні функції. Волостель здійснював контроль за перерозподілом земельних ресурсів, станом сільськогосподарських угідь, організацією торгівлі, охороною правопорядку, збором уроків і данини, стягував на користь великого князя судові штрафи [18, с. 219]. Судова функція волостеля була однією з його основних. За допомогою своїх тіунів волостель вирішував як цивільні, так і кримінальні справи, а судові мита слугували чималим джерелом волосних доходів. Утримувався волостель, як і посадник, не з державної скарбниці, а безпосередньо з підвладного йому населення (з корму, поборів, штрафів, частини данини і судового мита). Відсоток із волосного доходу волостелі сплачували в державну казну [39; 40, с. 128]. Посадники та волостелі мали багато слуг, тіунів, урядовців і помічників з окремих галузей, мечників, мостників, вирників та інших, які допомагали їм у здійсненні господарських, адміністративних і окремих судових функції [26].

Варто зазначити, що, на відміну від посадників, волостелі не розглядалися як самостійні політичні фігури, а компетенція волосної влади зосереджувалась на рівні підвідомчої території та не стосувалася військово-політичної та дипломатичної сфер, що, ймовірно, вказує на більший авторитет посадників у містах, аніж волостелів у сільській місцевості. Величина доходів посадників і волостелів залежала не від того, де вони були управителями (у містах чи волостях), а від розміру підвладної їм території. 3 розвитком феодальних відносин більшість із них перетворили свої посади на спадкові, а данину - на феодальну ренту, а із часом стали повноцінними феодалами. 
Волості існували переважно на півдні Русі, а на півночі держави були поширені погости. У середині Х ст. за правління княгині Ольги землі були поділені на окремі самоврядні адміністративно-територіальні одиниці - погости [1, с. 261-266]. Унаслідок реформування процесу збору данини і ліквідації племінних князівств була створена нова форма місцевої фінансової адміністрації. Спочатку погости являли собою місця-стоянки, де зупинявся великий князь разом зі своєю свитою, що слугували місцями збору народу для сплати данини, уроків. Згодом погости набули статусу окремих адміністративно-територіальних одиниць, що складалися з кількох населених пунктів у сільській місцевості та були спершу фінансово-адміністративними, а після прийняття християнства ще й церковними центрами земель-князівств. У центрі кожної такої самоврядної одиниці було представництво великокнязівської влади. Достовірних відомостей про те, хто стояв на чолі погостів, ми не знайшли, однак за аналогією можна припустити, що це були князівські намісники або ж старости, які мали той же обсяг повноважень і тіунів, що і волостелі. Також відомо, що погостом ще називали центральне поселення сільської округи (верви), де розташовувались спільні органи управління громади, ринок і церква. Основним призначенням погостів було полегшення збирання данини з місцевого населення [41; 42, с. 438].

Окремі адміністративні, військові, фіскальні і судові функції на місцях могли за дорученням великого князя здійснювати різні його тіуни - мечники, вірники, ключники, дітські, отроки, ябетники й інші службові особи. Інколи великий князь також об’іжджав свої володіння, щоб перевірити роботу місцевих посадовців і проконтролювати їхню добросовісність.

Цікавим є те, що управління фінансами на місцях перебувало в безпосередньому віданні самого великого князя. Для збирання мита та данини на територіях міст і волостей він відряджав уповноважених посадовців - митників, данщиків, п'ятенщиків, які не залежали від місцевої влади. Гроші, які вони збирали, вносилися безпосередньо великому князю, йому ж також скаржилися на неправомірні дії збирачів данини [19, с. 23].

В умовах розвитку інститутів публічної влади територіальні громади міст і сіл органічно вписались у систему державного управління земель-князівств. Давньоруська держава являла собою багаторівневу систему територіальних громад, у якій можна виокремити три основні ланки, як-от: громада старшого міста, громади підпорядкованих їй молодших міст (передмість) і сільські громади [43, с. 539]. Зі збільшенням території та населення держави вдосконалюється й система місцевого самоврядування. Містами тоді називалися великі територіальні громади, до яких примикали дрібніші громади. Вони ділилися на старші міста і передмістя та мали внутрішній адміністративно-територіальний поділ, зумовлений виробничим чинником і спеціалізацією населення. Старше місто, молодші міста (передмістя) і сільські поселення волості (погосту) становили адміністративно-територіальну єдність землі-князівства. Кожна волость отримала назву від старшого міста (наприклад, Київ - Київська земля, Новгород - Новгородська земля). Згодом волостями також називавали великі міста-держави, які мали ознаки внутрішнього суверенітету. Економічну основу місцевого самоврядування в містах становили громади, які 
поділялися за родом занять. Громад була велика кількість, усі вони являли собою виробничі і торговельні колективи, що проживали на різних вулицях чи в окремих частинах міста, до них належали вільні мешканці міст і ремісники, що об'єднувались у сотні (об’єднання за професіями), на чолі яких стояв соцький, а їхнім привілеєм було володіння зброєю. Зазвичай сотень у місті було приблизно десять, а на чолі сотень стояв тисяцький, який був командувачем ополчення міста і суддею в цивільних справах. Влада тисяцького поширювалася на всю територію старшого міста і передмістя. Під час військових дій влада тисяцького старшого міста набувала надзвичайного характеру, він міг скасувати рішення віча передмістя, коли воно йшло всупереч інтересам громади старшого міста або ж ставило під сумнів територіальну цілісність землі-волості. Подібно посаднику, тисяцький піклувалися про збереження єдності землі і робив все необхідне для припинення сепаратистських дій та придушення бунтів [22, с. 57].

Головним самоврядним органом громади старшого міста та волості загалом були народні збори - віче, у якому за давньоруськими звичаями брали участь вільні члени громади міста та його околиць. Брати участь у віче було не обов'язком, а правом членів громади. Однак цим правом наділялись не всі вільні жителі, а лише голови великих сімей, мужі та міське боярство, іноді на віче прибували делегати з передмість і князі. Рішення на віче ухвалювалися шляхом консенсусу. Якогось підрахунку голосів на користь того чи іншого рішення не проводилося, необхідна була тільки загальна згода віче, щоб рішення набрало чинності. На віче старшого міста обговорювались і вирішувались найважливіші питання, обиралися волосний староста та міські посадовці. Виборні посадові особи громади старшого міста (посадник, тисяцький, сотники, старости) були водночас і посадовими особами державного управління землі-князівства. Віче відало питаннями війни і миру, розпоряджання князівськими столами, фінансовими та земельними ресурсами волості, оголошувало грошові збори з волосного населення, обговорювало ухвалення нових законів, зміщувало представників князівської адміністрації та висувало свої кандидатури тощо. Компетенція віче старшого міста нічим не обмежувалась, а жителі, які на ньому збиралися, могли обговорювати й ухвалювати рішення з будь-яких важливих питань. На рішення народних зборів мали вплив старійшини громади, a із часом усе більше міське боярство. Велике значення мала також військова сила міської громади - так званого земського війська, до якого входило все доросле боєздатне чоловіче населення волості. Без згоди віче старшого міста князь не міг провести мобілізацію земського війська, що робило його майже безсилим перед зовнішньою та внутрішньою загрозами [31, с. 34-35].

Самоврядування менших міст (передмість) було організоване за тим же принципом, що й у старшому місті. Однак цікавим моментом є те, що носієм публічної влади виступала саме громада старшого міста, оскільки в її руках зосереджувалась примусова влада щодо жителів передмість і волості загалом. Отже, рішення громади старшого міста були обов'язковими для всіх жителів передмість. Адміністративна залежність менших міст від старшого міста виявлялася ще й у тому, що вони приймали від старшого міста посадників. Отже, самоврядування громади старшого міста і волості були нероздільними. 
Із часом старші міста перетворювались на політичні та культурні центри князівств. Успіх місцевих князів та їхній авторитет багато в чому залежали саме від підтримки міської громади. Громада старшого міста обирала князя, укладала з ним договір («ряд»), порушення умов якого могло призвести до настання небажаних для останнього наслідків. У Давньоруській державі діяв інститут вічового суду над князем, тому в разі зловживання ним владою, свавілля, скоєння злочину або інших неприпустимих дій громада старшого міста могла позбавити місцевого князя влади, вигнати його з міста і навіть стратити.

Найбільш поширеними на давньоруських землях були сільські територіальні громади - верви. Верв походить від родової общини стародавніх слов'ян, що об'єднувала кровних родичів, які вели спільне господарство. Однак із розкладом родоплемінного ладу дана форма організації місцевого самоврядування продовжила розвиватись уже на територіальній основі та почала об'єднувати одне або декілька сусідніх селищ, що розташовувались недалеко одне від одного і вели спільне сільське господарство [44, с. 105; 46]. Верв налічувала від десяти і більше дворів, де проживали великі сім’і, до неї також могли входити сім’і, які належали до різних родів. Територія верви була досить великою і могла охоплювати декілька населених пунктів у сільській місцевості. Верви об'єднувалися у волості та погости. Сільське населення того часу мало чим відрізнялося від міського, а головна відмінність полягала у способі виробництва та промислі. Зазвичай населення верви займалося землеробством, тваринним або рибним промислом і проживало в селищах, що були розкидані довкола міст. 3 Х ст. сільські громади тривалий час існували як самостійні територіальні одиниці [45, с. 71]. Основними причинами цього явища є величезна територія держави і недостатньо розвинена система сполучень між дрібними населеними пунктами, а також аграрний спосіб виробництва більшості територіальних громад на Русі. До того ж князівським волостелям і тіунам під час зборів данини було зручніше мати справу із громадою, ніж з кожною родиною окремо. Мешканців селищ, що входили до складу верви, пов'язувало спільне користування землею, колективна сплата данини й оброків до князівської казни, потреба взаємної допомоги, охорона земель від захоплення тощо. Усі члени верви були зв'язані один з одним круговою порукою і несли колективну відповідальність за злочини, що були вчинені на території громади, і за несплату данини. Члени сільських громад не були закріплені за конкретною землею, тому окремі родини або ж навіть цілі селища, які були незадоволені податками чи природними умовами, могли переселитися на інші землі.

У сільських громадах, як і у громадах міст, система самоврядування забезпечувалась сходом рівноправних общинників (віче), до яких входили голови дворів (родів, великих сімей), а також виборними посадовими особами - старостами, які стояли на чолі верв та обирались віче на певний час, імовірно, почергово [46, с. 6]. На сходах вирішувались найважливіші питання життя сільської громади, а рішення ухвалювалися простою згодою більшості її членів. Як самоврядна одиниця верв здійснювала спільну колективну власність на землю, представляла і захищала інтереси сільської громади в конфліктах із місцевим апаратом князівської влади і феодалами, підтримувала стосунки з іншими сусідніми громадами, 
а також вирішувала побутові питання. До основних самоврядних функцій верви можна віднести: адміністративну, господарсько-виробничу, представницьку, оборонну, поліцейську, судову та фіскальну [47, с. 176-177].

Варто зазначити, що поруч із вільними сільськими громадами існували також селища невільників. Деякі місцеві (удільні) князі розглядали землі, що були неподалік, як особисту власність, за користування ними обкладали місцеве населення різними повинностями й оброками. Нерідко князі передавали самовільно привласнені землі своїм дружинникам або духовенству разом із правом збирати з місцевого населення данину, стягувати деякі судові мита, а також учиняти суд, за винятком тих кримінальних справ, які підлягали суду великого князя [48, с. 105].

3 поширенням феодальних відносин давньоруськими землями з XI-XII ст. відбувається становлення двірсько-вотчинної системи, яка деякий час існувала паралельно з десятковою, але згодом цілком її витіснила [49, с. 133]. Двірсько-вотчинна система управління полягає в поєднанні управління приватними справами князя з державними. Упродовж X-XI ст. княжий двір був місцем, де жив великий князь разом зі своєю свитою, це була його домівка і резиденція. Досить тривалий час двір князя залишався малоструктурованим, а особи, що при ньому служили, не мали чітко визначених функцій, оскільки в цьому не було потреби [50, с. 57]. Однак із другої половини XI ст. із кола наближених до великого князя дружинників і бояр структурно оформлюється княжий двір як політичний і адміністративний центр держави, який згодом став взірцем для наслідування місцевою владою [17, с. 596]. Великий князь перетворився на князя-господаря, який розглядав державу як особисту власність, а кожен, хто входив до його двору і відав будь-якою сферою господарства, міг із дозволу свого господаря виконувати деякі управлінські функції. Відтоді двір князя став серцем Давньоруської держави, центром їі адміністративного апарату, через який вирішувалися адміністративні, економічні, політичні, релігійні й інші важливі питання. До складу двору могли входити від кількох десятків до декількох сотень осіб (залежно від розміру господарства князя), а сам двір князя являв собою сучасний аналог державної служби та мав деякі особливості, що відрізняли його від середньовічних аналогів Західної Європи. Оскільки тоді не існувало принципового розходження між органами державного управління й органами управління приватними справами князя, то особи, які входили до двору, наділялися певними управлінських функціями, а призначені на публічні посади чини двору утримували за собою ті найменування, що належали їм у господарстві князя [51, с. 202]. Усіх членів двору пов'язували особисті неформальні стосунки із князем, вони були його родичами, друзями, слугами, охоронцями, радниками, дружинниками і завжди були поруч. Зрозуміло, що для княжого двору були характерні суперництво й інтриги, які дещо врівноважувалися відносинами солідарності і взаємодопомоги [52, с. 26].

Літописи містять лише поодинокі згадки про прийом на службу до князівського двору, однак з історичних джерел нам відомо, що управлінський прошарок двору становили переважно знатні служиві і неслуживі люди, вихідці з вищих прошарків суспільства - дружинники та бояри, місцеві та приїжджі. Брали на службу також представників нижчих суспільних верств, а інколи слугами князя ставали 
навіть невільники та полоненні [17, с. 539]. Кандидати на службу оцінювалися за репутацією й особистими заслугами перед князем, тому двір як владний апарат був сталим і міцним, до нього зазвичай не входили випадкові люди [52, с. 26]. Посадовці двору вищого рангу могли обіймати посади різними способами. Так, деякі князі після смерті свого попередника лишали представників управлінської ланки на посаді, інші ж службовці отримували чини внаслідок поступового кар'єрного росту та довготривалої служби, зарекомендувавши себе з кращого боку на попередніх посадах нижчої ланки [17, с. 539].

При княжому дворі існували різні посади, на яких службовці сумлінно виконували покладені на них обов'язки. Найвищими за рангом посадовими особами при дворі були тіуни, які виконували різноманітні господарські функції й особисті доручення великого князя. Початково тіуни призначалися з кола найвідданіших слуг князя (переважно невільників), а пізніше обиралися з найближчих до князя старших дружинників, бояр і боярських синів, які на княжому дворі привчалися до державної служби. Згодом тіуни почали виконувати не лише господарські, а й адміністративно-управлінські, фінансові, фіскальні та навіть деякі судові функції. 3 удосконаленням княжого двору серед тіунів почала розвиватися спеціалізація. До основних посадовців двору належали: двірський (огнищний), стольник, покладник (постільничий), ключник, печатник (канцлер), конюшний, бирич (бирчий), ловчий, седельничий, збройник, мечник, ябетник, отроки, дитячі, вирник та інші службовці [53, с. 33].

Правою рукою князя вважався двірський (огнищний), який завідував усім князівським господарством, супроводжував його в дорозі і походах, виступав від його імені перед іншими посадовцями, брав участь у князівському суді, а також виконував особисті доручення свого господаря. У його віданні перебував увесь адміністративний апарат двору, усі палацові слуги, челядь і землі [54, с. 228]. Покладник (постільничий) завідував спальнею та ложем князя, стежив за його комфортом і безпекою всередині покоїв, а також відповідав за «постільну скарбницю» (ікони, хрести, золотий та срібний посуд, одяг тощо). Ключник відповідав за ключі від усіх покоїв і комор. Стольник завідував столом князя і постачанням продовольства до кухні, відповідав за організацію банкетів і прийомів. Печатник (канцлер) керував князівською канцелярією, був головний над писарями та перекладачами, відповідав за діловодство, зберігання князівської печатки, складання текстів грамот, актів, наказів, засвідчення документів, їх зберігання і розсилання. Окрім цього, печатник відав усіма доходами та видатками князя, виконував важливі державні завдання і відповідав за охорону скарбниці, що була тоді архівом. Зазвичай посаду печатника обіймали грамотні люди і священнослужителі [3, с. 190]. Конюшний завідував князівськими стайнями і табунами, був головним над всіма конюхами, а також відповідав за забезпечення князівського війська скакунами. Бирич (бирчий) був головним помічником князя в судових і дипломатичних справах, а також оголошував князівські накази по вулицях і площах серед народу. Ловчий відповідав за організацію полювання для князя. Седельничий супроводжував князя у військових походах і мандрівках, відповідав за князівське сідло та підготовку його коня до мандрівки, також був пові- 
реною особою князя і виконував його важливі доручення. Збройник відповідав за забезпечення князівського війська зброєю і за поповнення припасів [55, с. 129]. Мечник і ябетник належали до молодшої княжої дружини та були судовими виконавцями. Мечник завідував князівським арсеналом і брав участь у випробуванні залізом, на його користь надходила частина прибутків від судових зборів. Окрім того, мечникам інколи доручали вести дипломатичні переговори [4, с. 39]. Ябетник був присутнім на князівському суді та виступав державним обвинувачем. Отроки і дитячі були судовими виконавцями, а також виконували різні доручення двірського та самого князя [56]. Вірник теж був судовим виконавцем і збирачем штрафів за вбивство (віри). Вірникам у їхній справі допомагали нижчі за рангом службовці. Митники, данщики та п'ятеншики стягували мито і данину. Із часом окремі відомства двору почали очолювати старший конюх, стольник, ловчий та інші важливі посадовці. Поступово їхні посади перетворилися на двірцеві чини, а під їхнім керівництвом діяли численні князівські ключники. Будучи двірськими чинами, вони набули низку публічних функцій, що дозволяло їм керували певним родом занять у масштабах усього князівства [53, с. 33]. Окреме місце серед посадовців двору посідав тисяцький, який був начальником збройних сил старшого міста і землі-князівства, у разі відсутності князя вставав на чолі війська. На перших порах воєводами нерідко ставали досвідчені воїни-чужинці, які із власних міркувань були особисто віддані великому князю. 3 розвитком двору воєводою міг стати будь-хто з його службових осіб [30, с. 61]. Усіх посадовців двору призначав особисто великий князь, тому вони відповідали безпосередньо перед ним. Велика частина посадовців двору відряджалися до інших міст і волостей для виконання різноманітних адміністративних, господарських, фіскальних і судових функцій на місцях. Вищим посадовим особам двору прислуговували нижчі за рангом тіуни та двірцеві слуги [3, с. 196.]. Увесь апарат двору утримувався з поборів, зібраних із місцевого населення.

Князівський двір складався не лише з персоналу, який обслуговував палац і господарство. Князь потребував присутності військових, які б завжди були поруч, тому певна кількість воїнів жили при дворі на повному його утриманні. Вони називалися за віком - отроками, а за зброєю - гридями і мечниками [19, с. 23].

Цікавим є те, що, у разі потреби, двір міг переміщуватися разом зі своїм господарем з однієї місцевості в іншу. Наприклад, коли князь переходив на інший стіл або ж коли, у разі небезпеки, потрібно було терміново залишити місто. Також в умовах феодально роздрібненої держави князю разом із підданими та військом інколи було необхідно перебувати в тій частині держави, де існувала реальна загроза його владі [57, с. 35-41].

Особливістю двірцево-вотчинної системи є її прямий зв'язок із феодальним принципом належності адміністративно-управлінської влади безпосередньому землевласнику. Двірцево-вотчинне управління існувало не лише при дворі Київського князя, але й абсолютно на всіх рівнях феодальної ієрархії того часу. У XII ст. в умовах феодальної роздрібненості Давньоруська держава перетворилась на типову сюзеренно-васальну монархію, а великий князь здійснював управління на місцях через своїх васалів. Тоді ж остаточно утвердилась і система місцевого 
управління, яка цілком повторювала модель управління Києва. Отже, у містах, волостях, погостах і боярських вотчинах двір разом з усіма тіунами та слугами став типовою основою місцевої влади, а двірцево-вотчинна система остаточно витіснила стару десяткову модель управління державою.

Поширення вотчинного землеволодіння сприяло тому, що більша частина старшої служивої знаті поступово віддалилась від князівського двору, перейшла до власних земельних наділів. 3 кінця XII ст. більшість бояр і старших дружинників при дворі великого князя були замінені молодшими. Із часом молодша дружина розчинилася у княжому дворі, де все більше служивих осіб - люди різного, переважно незнатного, походження [3, с. 93].

Варто зазначити, що на формування місцевої адміністрації двору мали вплив міська та сільська громади, що могли ініціювати відставку конкретного посадовця або ж, навпаки, вимагати надання певної двірської посади комусь із більш гідних кандидатів [5, с. 34].

3 поширенням феодальних відносин, крім князівського, усе більшого розвитку набуває боярське і церковне землеволодіння. До XII ст. виникла вотчинна форма власності, за якою землю можна відчужувати або передавати у спадок, а селяни, які на ній проживали, не лише повинні були сплачували данину великому князю, а й ставали феодально залежними від їі власника - боярина, виплачували йому за користування землею натуральну ренту. Перші ознаки боярського землеволодіння можна простежити ще в XI ст. [58, с. 26]. Унаслідок поступового процесу ієрархізації всередині дружини відбулося її розшарування на старшу (мужі, бояри) та молодшу (отроки, діти бояр) дружину [59, с. 40], за службу старші дружинники одержували від великого князя землі [60, с. 67]. Термін «боярин» уживали тоді стосовно знатних і заможних людей [17, с. 416], але тільки на початку XII ст. цим терміном почали називати суспільний прошарок давньоруської служивої аристократії, що утворився внаслідок майнового розшарування дружини $[61$, c. 94]. Серед науковців немає єдиного погляду на процес формування та структуру боярства. Одні вченні вважають, що бояри належали до служивих мужів і були керівною верхівкою князівської дружини, оскільки сам термін «боярин» ніколи не вживався щодо неслужилої знаті [59, с. 48]. Інші ж науковці в результаті проведеного аналізу процесу становлення боярства дійшли висновку, що поруч зі служивими князівськими мужами були і неслужива племінна знать та її нащадки [17, с. 540]. Часто старші дружинники обіймали вищі керівні посади в палацовому і місцевому управлінні, служили радниками, тіунами та посадниками, тисяцькими, соцькими тощо. Деякі старші дружинники навіть могли мати власні військові дружини. Наприклад, боярські отроки входили в особливі загони, які не зливалися з отроками, безпосередньо підлеглими великому князю [62, с. 73]. Із XII ст. князь почав надавати старшій дружині в пожалування землі та волості під управління і «годування». Так представники старшої дружини зайняли найвищу управлінську сходинку та мали вплив на політику великого князя, дістали назву «бояри». Із часом боярські вотчини набули чималої автономії та вийшли з-під влади великого князя, а населення, яке на них проживало, стало цілковито підвладним боярам. 
Боярські вотчини мали власні органи влади. На чолі вотчини стояв боярин (феодал) - сюзерен великого князя, який управляв землею за допомогою апарату власного двору, який був схожий на князівський. Бояри були пов'язані з великим князем відносинами сюзеренітету-васалітету, що зумовлювало їхні взаємні зобов'язання. Боярин ніс перед сюзереном військову повинність, у разі потреби відправляв йому своє ополчення, брав участь у князівській раді (коли отримував запрошення від князя), надавав гроші, коли князь одружував свою дочку. Великий князь повинен був захищати боярина (у разі загрози для його життя, зокрема військової) і міг запросити його до участі у князівській раді. Якщо боярин хотів змінити свого сюзерена, князь мав відпустити його, однак таке траплялося вкрай рідко, оскільки князь і бояри часто були пов'язані один з одним ще й певними особистими зв'язками. Окрім права на збір повинностей, боярин також наділявся правом чинити суд над підвладним йому населенням.

До основних службових осіб вотчинної адміністрації належали огнищний, конюшний, сільський і ратайний тіуни. Тіун огнищний був своєрідним намісником боярина, який завідував усім господарством і від імені господаря здійснював владу над населенням вотчини, а також відповідав за збереження боярського майна [63, с. 398]. У розпорядженні огнищанина перебували решта тіунів і слуг. Конюшний був головним над всіма конюхами і відповідав за всіх коней у боярському господарстві та за їх розведення [63, с. 406]. У сільських громадах, які проживали на феодальних вотчинах, також були представники боярської адміністрації - сільський і ратайний тіуни (старости). Спочатку сільський староста був виборною особою, однак із перетворенням землі громади на боярську власність, а селян - на феодально залежних смердів він став представником боярина. До його основних функцій належало: ведення справ сільської громади, здійснення нагляду та контролю за виконанням населенням вотчини феодальних повинностей, доповідання боярину про результати виконаних робіт у межах господарства, а також щодо сплати натуральної данини і відпрацювання смердів. Ратайний староста відповідав за здійснення польових робіт і стежив за якістю та черговістю їх проведення [63, с. 408].

Необхідно також згадати про церковне самоврядування на Русі. Прийняття християнства сприяло централізації влади, придушенню сепаратизму племінних князів-вождів та утвердженню єдиновладдя великого князя Київського. На статус і авторитет церкви істотно вплинуло не тільки ставлення князівської влади до християнства, а й матеріальний стан самої релігійної організації. На перших етапах становлення церковної організації (кінець X - початок XI ст.) церква, яка перебувала в релігійній (і політичній) залежностю від Візантії, намагалася пристосувати свою діяльність до місцевих звичаїв, не переймаючи іноземного зразка. Спочатку новий культ діяв за «язичницьким» принципом, а церковне право збагатилося нормами варварського і ранньофеодального світського права. Внутрішній церковно-адміністративний устрій відповідав тогочасному адміністративно-територіальному поділу держави на землі-князівства, що, у свою чергу, поділялись на волості та погости. Через декілька років після запровадження християнства була створена церковна організація - митрополія [24, с. 102]. У ранньофеодальний період у Давньоруській державі існувала одна митрополія, що об’єднувала декілька єписко- 
пій. Адміністративно-територіальна організація давньоруської церкви складалась з одного митрополита і невеликої кількісті (від 10 до 15) єпископій, що повторювали систему підпорядкування земель-князівств Києву, а не Візантійську модель [64, с. 341, 368-369]. Основу внутрішньої організації єпархій становили центри парафії-погости, які територіально збігалися з межами влади князівських посадників. Управління в парафіях здійснювали намісники єпископа.

Духовенство того часу поділялося на чорне (ченці та черниці) і біле (мирське) - священики, диякони, дяки, паламарі, причетники, до них належали середні та малозабезпечені верстви населення, які перебували під юрисдикцією церкви. До верхівки духовенства належали митрополит, єпископи, архімандрити й ігумени монастирів. Духовенство кількох церков об'єднувалося в собор, який обирав зі свого середовища двох церковних старост, які керували справами собору. Вищі церковні посади віддавалися переважно вихідцям із Візантії. Митрополит висвячувався Константинопольським патріархом, обирався патріаршим собором й інтронізувався на кафедру в Києві в Софійському соборі, за згодою великого князя Київського. Єпископи були високопоставленими церковними сановниками, влада яких пізніше прирівнювалась до становища місцевих князів. Призначення єпископів (усупереч канонічному праву) зазвичай було прерогативою самого великого князя. Спископи мали власний адміністративно-управлінський апарат, який за структурою нагадував князівський [65, с. 87]. Діяльність церковних посадовців перебувала під безпосереднім контролем держави, тому не дивно, що призначені вищі чини духовенства шукали союзу з великокнязівською владою, від якої вони залежали, насамперед економічно.

На Русі тривав процес утворення нових єпископій, перші з яких були створені у великих містах поблизу Києва - Новгороді та Білгороді, а згодом у Переяславі, Чернігові, Полоцьку, Турові, Юр'єві та в інших містах. На приєднаних і захоплених землях для зміцнення свого впливу київські князі доручали церкві проводити місіонерську діяльність, а новоутворені єпископії повинні були сприяти християнізація окраїн держави, де все ще проживали численні племена [66, с. 127-128]. Церква швидко взяла під свій контроль частину суспільних інститутів, однак не зазіхнула на юрисдикцію великого князя. До відання церкви відійшов розгляд справ про шлюб і сім’ю, розлучення, спадкування, захист честі та гідності, вирішення внутрішньоцерковних конфліктів і суперечок щодо мирян, соціального спокою, а також налагодження та підтримання зовнішньополітичних відносин усім цим займались церковні чини різних рівнів. Із часом представники вищого духовенства очолювали дипломатичні місії та навіть виступали послами й посередниками між різними ворогуючими князівськими династіями. Зі зміцненням авторитету церкви в Давньоруській державі поряд зі світською юрисдикцією функціонувала єпископська, сфера впливу якої була зафіксовані в писаних правових нормах «Руської правди», князівських статутах, а також візантійських кодексах і церковних збірниках [67, с. 248-254, 257].

3 кінця X ст. київські князі надавали церкві різного роду пожалування. Князь Володимир установив «десятину» і віддавав на користь церкви десяту частину від своїх прибутків, а на початку XI ст. церква отримала ще й право суду, що можна 
простежити із князівських церковних статутів і статутних грамот [67, с. 121-125]. Отже, церква отримувала чималі прибутки від десятини, церковного суду та пожертвувань вірян. У літописних джерелах до кінця XI ст. відсутня інформація про те, що окремі церкви, монастирі чи єпископії мали у власності земельні ділянки, є лише згадки про отримання церквами десятини від данин і князівського суду [68, с. 492-493]. Окрім цього, церковні організації також отримували прибутки від церковних судів, юрисдикція яких поширювалася на шлюбно-сімейні відносини, що раніше перебували у віданні судів місцевих громад. У середині XI ст. церковне судочинство отримало юридичне оформлення у статуті князя Ярослава і митрополита Київського Іларіона [66, с. 125]. До сфери впливу давньоруської церковної організації також належала й освітянська діяльність, а при церквах діяли парафіяльні навчальні заклади, де під керівництвом місцевого духовенства виховувалися і навчалися діти [69, с. 10$]$.

Уже у XI ст. поруч із міськими і волосними громадами з'являються церковні та монастирські громади, які об'єднувались навколо церков і соборів [58, с. 26]. Князі почали передавати у володіння церкви землі разом із населенням, яке на них проживало. Цілком вірогідно, що разом із землею церкві надавалось і право збору податків із місцевого населення, за аналогією до боярських вотчин [70, с. 142143]. Отже, унаслідок захоплення не зайнятих і общинних земель, дарувань місцевих князів церква поступово перетворилась на великого землевласника і стала повноправним суб'єктом місцевого самоврядування. 3 XI-XII ст. оформлюється церковна власність на землю. Перші згадки про подаровані церквам землі датуються кінцем XI ст. Правда, земельні дарування доповнювали виділення данин із певних волостей [68, с. 492-493]. Великими землевласниками стали єпископські кафедри, монастирі, собори, однак передача церкві земельних ділянок супроводжувалася низкою заборон: не дозволялося продавати, передавати, дарувати отриману землю [71, с. 141]. У першій половині XII ст. у власність церкви передавались села й угіддя [72, с. 329-330], а розміри церковного землеволодіння стрімко збільшувалися [73, с. 348]. 3 перетворенням церкви на великого землевласника десятина стала особливим податком, який збирали церковні служителі, а не князівські посадовці [64, с. $516 ; 74$, с. 103].

Цікавим є питання про ієрархію всередині давньоруської церкви. Зрозуміло, що Київська митрополія мала найвищий статус, а інші підлеглі їй єпископські кафедри були рівноправними, хоча на практиці їхній вплив напряму залежав від розмірів земельних наділів. Оформлення церковної власності на землю сприяло послабленню економічної залежності єпископій від Києва, які перетворювалися на самоврядні місцеві організації. Унаслідок зіткнення інтересів князівської влади і церкви більшість єпископів не були допущені до участі в державних справах великого князя [75, с. 71-78]. Тому місцеве духовенство прагнуло союзу з місцевими (удільні) князями, боярами, а також із претендентами на князівський престол, оскільки ті виступали основним гарантом матеріального благополуччя церкви. Зростання авторитету церкви змушувало місцевих князів і бояр залучати вище духовенство до вирішення важливих управлінських питань, зокрема й до участі у князівських з'їздах (наприклад, для обговорення передачі престолу 
тому або іншому князю). Участь церкви була необхідна для того, щоб зробити рішення з'їздів освяченими духовною владою [66, с. 132]. Відтак, можна простежити залежність єпископів від князівської влади, але давньоруська церква в особі вищого духовенства все ж користувалась великим авторитетом і впливала на політичне життя держави [76, с. 95-101].

Період феодальної роздробленості на Русі також відобразився на організаційній структурі церкви. Поява тріумвірату сприяла виникненню поруч із Київською ще двох нових митрополій - Чернігівської та Переяславської [77, с. 86], оскільки церква будувала свою організацію за феодально-ієрархічним зразком, наслідувала структуру державного устрою. Можна простежити цікаву тенденцію зближення інтересів самостійних князівських династій та місцевого духовенства. У боротьбі за самостійність своїх вотчин місцеві (удільні) князі прагнули обзавестися власним єпископом, що надавало б їхнім землям більшої автономності від центру (Київ). Сприяло цьому послаблення авторитету Київського митрополита, який у XII ст. лише формально затверджував ставлеників князів [64, с. 552-553]. Цілком закономірно, що прагнення до автономії місцевих князівств призвело до автокефалії місцевої церковної організації. Підтвердження цьому можна знайти ще в середині XI ст., коли сини Ярослава Мудрого, які отримали у спадок самостійні земельні наділи, поспішили сформувати окремі митрополії: Київську, Чернігівську і Переяславську. Тоді ж на Русі деякий час було аж три митрополити [78, с. 87-88]. $\mathrm{y}$ період роздробленості давньоруська церква отримувала стабільний дохід із земель, що перебували в загальнодержавному користуванні, та мала власний апарат для збору поборів із місцевого населення без опори на князівську адміністрацію [79, с. 93]. Із літописних джерел відомо, що, окрім земельних наділів, у власність церкви нерідко передавалось рухоме і нерухоме майно, маєтки, а інколи навіть цілі села з їх мешканцями [73, с. 348]. Наприкінці XII ст. до відання церкви відійшов такий інститут, як служба мір і ваг. Згідно з договором Смоленська з Ригою (1229 р.), проєктом договору Новгорода з Любеком (1269р.), статутами Володимира і Всеволода (початок XIII ст.), єпископські кафедри стали здійснювати нагляд, отже, і юрисдикцію щодо цього важливого питання. Цілком імовірно, що ця сфера перейшла від міських і князівських органів до відання місцевих єпископів [66, с. 131]. Отже, за церковним правом, місцеві церковні організації могли самостійно здійснювати церковно-адміністративну владу в межах своїх єпархій, а такі сфери суспільного життя, як мораль, сімейно-шлюбні відносини, спадкування, контроль за мірами і вагами, покарання за деякі кримінальні злочини, питання честі та гідності, були віднесені до сфери церковного права. Владу на місцях церква здійснювала через єпископських чиновників.

Отже, можна зробити висновок, що система органів місцевої влади Давньоруської держави кінця з IX-XIII ст. змінювалась і мала свої особливості в різні періоди історії. Десяткова система управління не відокремлювала центральне управління від місцевого і досить тривалий час не існувало чітко визначених органів місцевої влади з конкретним розподілом владних повноважень між посадовцями. Управління в містах здійснювали воєводи гарнізонів князівської дружини - тисяцькі, соцькі і десяцькі, які призначались великим князем, а також виборні посадові 
особи - старці (старости) у селах. Основу місцевого самоврядування становили територіальні громади мешканців міст і сіл, а їхнім головним самоврядним органом були збори вільних членів громади - віче, на якому вирішувались усі найважливіші питання й обиралися старці.

Після адміністративних реформ Х ст. територія Русі була поділена на землі-князівства, а ті, у свою чергу, на волості та погости. Тоді управління у великих містах і передмістях здійснювали посадники великого князя - князівські сини, мужі, місцеві князі та князі-вожді, волостелі у волостях, тіуни князя в погостах, а виборні посадові особи - тисяцькі та соцькі в містах і старости в селах (верви). Давньоруська держава являла собою багаторівневу систему територіальних громад, у якій можна виокремити громади старшого міста, громади підпорядкованих їй молодших міст (передмістя) і сільські громади (верви). Самоврядування громади старшого міста та волості були нероздільними, однак головним носієм влади виступала саме громада старшого міста, а в її руках зосереджувалась примусова влада над жителями передмість і волості загалом. Незмінними в містах і селах лишились вічові традиції, де всі найважливіші питання вирішувались на віче, там же й обирались виборні посадові особи.

3 поширенням феодальних відносин в XI-XII ст. відбувалось становлення двірцево-вотчинної системи управління, яка деякий час співіснувала з десятковою, але згодом цілком її витіснила. Княжий двір поступово перетворився на основний політичний і адміністративний центр управління державою не тільки на центральному, а й на місцевому рівнях. У той період не було особливої різниці між органами державного управління й органами управління приватним господарством князя, а особи, які входили до його двору, також наділялися деякими управлінськими функціями. Із часом у великих містах і волостях двір разом з усіма його тіунами став типовою моделлю місцевої влади. Окрім князівського землеволодіння, усе більшого поширення набуло боярське та церковне. Виникла вотчинна форма власності, за якою землю можна відчужувати або передавати у спадок разом із населенням, а селяни, які на ній проживали, ставали феодально залежними від її власника - місцевого (удільного) князя чи боярина і виплачували йому за користування землею натуральну ренту й обкладалися іншими поборами. Церква тоді не тільки перетворилася на великого землевласника, а також отримала право на самоврядування в межах своїх єпархій.

Iз XII-XIII ст. Давньоруська держава перетворилась на типову сюзеренно-васальну монархію, а великий князь здійснював управління на місцях через своїх васалів - місцевих князів і бояр.

\section{Jimepamypa}

1. Грушевський M.С. Нарис історії Київської землі від смерті Ярослава до кінця XIV ст. Київ : Наукова думка, $1991.560 \mathrm{c.}$

2. Грушевський М.С. Історія України-Руси : в 11-ти т., 12 кн. / редкол. : П. Сохань (гол.) та ін. Київ : Наукова думка, 1993. Т. 3. 592 с.

3. Котляр М.Ф. Княжа служба в Київській Русі. Київ : Інститут історії України НАН України, 2009. $251 \mathrm{c}$.

4. Котляр М.Ф. Княжий двір Галича. Княжий двір Південної Русі X-XIII cm. / М.Ф. Котляр, В.М. Ричка. Київ, 2008. 357 с. 
5. Котляр Н.Ф. Княжеская администрация в Древней Руси. История и источниковедение. № 2 (40). С. 28 М.Ф. Котляр, В. Ричка 40.

6. Ричка В.М. «Вся королівська знать» (Влада Київської Русі). Київ : Інститут історії України НАН України, 2009. 180 с.

7. Толочко П.П. Київ і Київська земля XII-XII ст. Київ : Наукова думка, 1980. 222 с.

8. Толочко П.П. Древнерусский феодальный город. Киев : Наукова думка, 1989. 256 с.

9. Толочко П.П. Київська Русь. Київ : Абрис, 1996. 360 с.

10. Терещенко Ю.І. Україна і європейський світ : Нарис історії від утворення Старокиївської держави до кінця XVI ст. : навчальний посібник. Київ : Перун, 1996. 496 с.

11. Юшков С.В. Нариси з історії виникнення і початкового розвитку феодалізму в Кийвській Русі. Київ : Видавництво Академії Наук УРСР, 1939. 210 с.

12. Юшков С.В. История государства и права России (IX-XIX вв.). Изд. доп. и перераб. Ростов-на-Дону : Феникс, 2003. 735 с.

13. Юшков С.В. К вопросу о политических формах Русского феодального государства до XIX в. Вопросы истории. 1950. № 1. С. 71-93.

14. Беляев И.Д. Лекции по истории русского законодательства. Москва : Тип. А.А. Карцева, $1888.220 \mathrm{c.}$

15. Владимирский-Буданов М.Ф. Обзор истории русского права. 6-е изд. Санкт-Петербург ; Киев, 1909. С. $75-77$.

16. Затыркевич М.Д. О вліяніи борьбы между народами и сословіями на образованія Русскаго Государства въ домонгольскій періодъ. Главы IV-VIII. ЧОИДР. 1873. Кн. 2. C. 107-306.

17. Свердлов М.Б. Домонгольская Русь : Князь и княжеская власть на Руси VI - первой трети XII в. Санкт-Петербург : Академический проект, 2003. 736 с.

18. Свердлов М.Б. Генезис и структура феодального общества в Древней Руси. Ленинград : Наука, $1983.239 \mathrm{c}$.

19. Сергиевич В.И. Вече и князь : Русское государственное устройство и управление во времена князей Рюриковичей. Москва : Тип. А.И. Мамонтова, 1867. 413 с.

20. Пресняков А.Е. Княжое право в древней Руси : очерки по истории X-XII столетий. СанктПетербург, 1909. VIII. 316 с.

21. Ключевский В.О. Русская история : Полный курс лекций. Минск : Харвест, 2003. Т. І. 592 с.

22. Фроянов И.Я. Киевская Русь : очерки соціально-политической истории. Ленинград : Издательство Ленинградского университета, 1980.256 с.

23. Карамзин Н.М. История Государства Российского : в 12-ти т. ; в 3-х кн. Москва : 000 «Издетельство «АСТ»»; ЗАО НПП «Ермак», 2004. Кн. 1. T. I-IV. 668 с.

24. Повесть временных лет : Текст и перевод. Москва ; Ленинград : Изд. АН СССР, 1950. Ч. 1. 404 с.

25. Ипатьевская летопись. Полное собрание русских летописей. Санкт-Петербург : Издательство Императорской археографической комиссии, 1908. Т. $2.940+88$ с.

26. Правда руська. Тексти на основі 7 списків та 5 редакцій / склав та підготував до друку проф. С.В. Юшков. Київ : ВУАН, 1935. Ред. IV. С. 137-144. Ст. 42. Кр. Пр. ; ст. 9, 10, 74 Пр. Пр.

27. Слово о полку Ігоревім та його поетичні переклади й переспіви в українській літературі / видання підготував Олекса Мишанич. Акта, 2003. С. 565-579.

28. Владимирский-Буданов М.Ф. Обзор истории русского права. 6-е изд. Санкт-Петербург ; Киев, 1909. С. $75-77$.

29. Історія держави і права України : у 2-х ч. : підручник для студентів юридичних вищих навчальних закладів і факультетів / за ред. А.Й. Рогожина. Київ : Ін Юре, 1996. Ч. 1. 368 с.

30. Папакін Г.В. Історія державних установ України : Урядуючі інституції та державні установи IX - початку XX ст. ; НАН України. Інститут історії України ; Національна академія керівних кадрів культури і мистецтва. Київ : Інститут історії України, 2010. 243 с.

31. Институты самоуправления : историко-правовое исследование / В.Г. Графский и др. ; ред. Л.С. Мамут ; РАН, Институт государства и права. Москва : Наука, 1995. 301 с.

32. Довнаръ-Запольській М.В. Князь, его дума и администрація. Русская история въ очеркахъ и статьлх / под ред. М.В. Довнаръ-Запольскаго. Москва : Московское учебное книгоиздательство, 1912. T. 1. C. $248-268$.

33. Посадник. Юридична енииклопедія : у 6-ти т. / за ред. Ю.С. Шемшученка (відп. ред.) та ін. Київ : Українська енциклопедія ім. М.П. Бажана, 2002. Т. 4 : Н - П. 720 с. 
34. Гневушевъ А.М. Господин Великій Новгородъ. Русская история въ очеркахъ и статьях / под ред. М.Б. Довнаръ-Запольскаго. Москва : Московское учебное книгоиздательство, 1912. T. 1. С. $367-407$.

35. Котляр М.Ф. Посадник. Енциклопедія історї України : у 10-ти т. / редкол. : В.А. Смолій (голова) та ін. ; Інститут історії України НАН України. Київ : Наукова думка, 2011. Т. 8 : Па - Прик. 520 с.

36. Мателешко Ю.П. Рівні, типи та функції руського посадництва (кін. IX - поч. XII ст.). Грані. 2007. № 3. С. 8-12.

37. Спадщина поколінь. Прадавні українські літературні пам'ятки / Повість минулих літ. Київ : Грамота, 2005. $591 \mathrm{c.}$

38. Завадская С.В. К вопросу о «старейшинах» в древнерусских источниках XI-XIII вв. Древнейшие государства на территории СССР : материалы и исследования : 1987. Москва, 1989.

39. Летопись по Лаврентьевскому списку. Издание Археографической комиссии. Санкт-Петербург, 1872.

40. Греков Б.Д. Киевская Русь. Москва: Госполитиздат, 1953. 569 с.

41. Погост. Малый энциклопедический словарь Брокгауза и Ефрона : в 4-х т. Санкт-Петербург, 1907-1909.

42. Дьяченко Григорий, протоиерей. Полный церковно-славянский словарь. Москва, 1993. С. 438.

43. Яхшиян О.Ю. Крестьянская община и местное самоуправление в России. Российская государственность : исторические традиции и вызовы XXI века : материалы Всероссийской научнообщественной конференции, 19 сентября 2012 г., Великий Новгород. Москва : Научный эксперт, 2013. С. 539.

44. Баран Я.В. Верв. Енииклопедія історї̈ України : у 10-ти т. / редкол. : В. А. Смолій (гол.) та ін. ; Інститут історії України НАН України. Київ : Наукова думка, 2003. Т. 1 : А - В. 688 с.

45. Надолішній П.І. Вітчизняна традиція демократичного врядування як аспект національного державотворення: до 360 річниці конституції Пилипа Орлика. Вісник державної служби. 2009. № 4 . C. $69-78$.

46. Хрестоматия по истории России с древнейших времен до наших дней : учебное пособие / А.С. Орлов и др. Москва : Проспект, 1999. 589 с.

47. Прижов І.Г. Нариси. Статті. Листи. Москва ; Ленінград, 1934. С. 176-177

48. Чичерин Б.Н. Опыты по истории русского права : сборник статей. Москва : Изд. Солдатенкова и Щепкина, 1858. XII. 389 с.

49. Давня історія України : у 2-х кн. / П.П. Толочко та ін. Київ : Либідь, 1995. Кн. 2.224 с.

50. Історія державної служби в Україні : у 5-ти т. / О.Г. Аркуша та ін. ; за ред. Т.В. Мотренко та ін. ; Голов. упр. держ. служби України, Ін-т історії НАН України. Київ : Ніка-Центр, 2009. Т. 1. 544 с.

51. Атоян О.И. История государства и права Украины : с древнейших времен до середины XVII в. : Курс лекций / отв. ред. А.Н. Литвинов ; МВД Украины, Луган. ин-т внутр. дел. Луганск : РИО ЛИВД, 2001. $472 \mathrm{c}$.

52. Нариси історії державної служби в Україні / О.Г. Аркуша та ін. ; редкол. : С.В. Кульчицький (керівник авт. кол.) та ін. ; Голов. упр. держ. служби України, Ін-т історії України НАН України. Київ : Ніка-Центр, 2009. 533 с.

53. Проценко Ю.Л. Древнерусское государство и право : лекция . Волгоград: Изд-во ВолГУ, 2000. $60 \mathrm{c.}$

54. Літопис Руський. Пер. з давньорус. Л.Є. Махновця / за ред. О.В. Мишанич. Київ : Дніпро, $1989.591 \mathrm{c}$.

55. Софроненко К.А. Общественно-политический строй Галицко-Волынской Руси XI-XIII вв. Москва : Госполитиздат, 1955. 140 с.

56. Зимин А.А. Правда русская. Часть третья. Правда Русская в правовой традиции XII-XVII вв. Глава первая. Правда Русская в Новгороде, Пскове, Смоленске и Галиче в XII-XV вв. Москва : Древлехранилище, $1999.411 \mathrm{c}$.

57. Котляр М.Ф. Мобільність княжого двору в Південній Русі. Україна в Центрально-Східній Євponi. 2008. № 8. С. 35-52.

58. Рожков Н.А. Город и деревня в русской истории : краткий очерк экономической истории России. Петроград, 1919. 126 с.

59. Горский А.А. Древнерусская дружина : К истории генезиса классового общества и государства на Руси. Москва : Прометей ; МГПИ им. В.И. Ленина, 1989. 124 с. 
60. Бойко О.Д. Історія України : посібник. 2-ге вид., доп. Київ, 2002. 662 с.

61. Завадская С.В. «Болярин» - «боярин» в древнерусских письменных источниках. Древнейшие государства на территории СССР : материалы и исследования. 1985 г. Москва : Наука, 1986. С. 89-94.

62. Павлов-Сильванский Н.П. Государевы служилые люди. Москва : Крафт+, 2008. 288 с.

63. Правда русская. Москва ; Ленинград : Изд-во АН СССР, 1940. Т. 1.506 с.

64. Голубинский Е.Е. История русской церкви. 2-е изд., испр. и доп. Москва : Университетская типография, Страстной бульвар, 1901. Т. 1. Период первый. Первая половина тома. 960 с.

65. Моця О.П., Ричка В.М. Київська Русь : від язичництва до християнства. Київ : Глобус, 1996. $224 \mathrm{c}$.

66. Введение христианства на Руси / Ин-т философии АН СССР ; отв. ред. А.Д. Сухов. Москва : Мысль, 1987. 302 с.

67. Щапов Я.Н. Княжеские уставы и церковь в Древней Руси XI-XIV вв. Москва : Наука, $1972.338 \mathrm{c}$.

68. Полное собрание русских летописей (ПСРЛ). Санкт-Петербург, 1843. Т. 2 : Ипатьевская летопись. 386 с.

69. Саган О.Н. Відзначення 1020-ліття хрещення Київської Русі : першооснови та сьогодення духовної традиції українського народу. Пал'ять століть. 2008. № 3. С. 6-15.

70. Артамонов Г.А. Земля и власть в Киевской : дис. ... канд. ист. наук. Москва, 1996. С. 142-143.

71. Грамоты Великого Новгорода и Пскова / под ред. С.Н. Валка. Москва : Изд-во АН СССР, $1949.407 \mathrm{c}$.

72. Щапов Я.Н. Церковь в системе государственной власти древней Руси. Древнерусское государство и его международное значение. Москва : Наука, 1976. С. 329-333.

73. Полное собрание русских летописей, изданное по высочайшему повелению археографической комиссии. Санкт-Петербург, 1846. Т. 1 : Лаврентьевская и Троицкая летописи. 392 с.

74. Патерик Києво-Печерський / упоряд., адапт. укр. мовою, дод. і прим. І.В. Жиленко ; відп. ред. В.М. Колпакова. 2-ге вид. Київ, 2001. 348 с.

75. Щапов Я.Н. Устав князя Ярослава и вопрос об отношении к византийскому наследию Руси в середине XI в. Византийский временник. Москва, 1971. Т. XXXI. С. 71-78.

76. Соловьев С.М. История России с древнейших времен : в 15-ти т. Москва, 1959. Кн. 1 (тома 1-2); 1960. Кн. 2 (тома 3-4). С. 62-63.

77. Поппе А.В. Русские митрополии Константинопольской патриархии в XI ст. Византийский временник. Москва, 1968. Т. XXVIII. С. 86-96.

78. Назаренко А.В. Митрополии Ярославичей во второй половине ХІ в. Древняя Русь. Bопросы медиевистики. 2007. № 1 (27). С. 85-103.

79. Щапов Я.Н. Государство и Церковь в Древней Руси Х-ХІІІ вв. Москва, 1989. С. 86-97.

\section{Анотація}

Карпічков В. О. Становлення та розвиток органів місцевої влади в Давньоруській державі. Стаття.

У статті досліджено органи місцевої влади в Давньоруській державі кінця IX-XIII століть, їхню структуру й особливості.

Установлено, що десяткова система не розділяла центральне управління від місцевого, а владу на місцях до X століття здійснювали воєводи князівської дружини - тисяцькі, соцькі та десяцькі, які призначались великим князем, і виборні посадові особи - старці (старости) у селах. Основу місцевого самоврядування становили громади міст і сіл, а їхнім головним органом було віче, на якому вирішувались усі найважливіші питання й обиралися старці.

Після адміністративних реформ X століття територія Русі була поділена на землі-князівства, а ті, у свою чергу, на волості та погости. Управління у великих містах тоді здійснювали посадники великого князя - князівські сини, мужі, місцеві князі та князі-вожді, волостелі у волостях, намісники князя в погостах, а також виборні посадові особи - тисяцькі та соцькі в містах і старости в селах. На той час держава являла собою багаторівневу систему територіальних громад, у якій можна виокремити громади старшого міста, громади підпорядкованих їй молодших міст (передмість) і сільські громади (верви). Самоврядування громади старшого міста, менших міст і волості були нероздільними, однак головним носієм влади виступала саме громада старшого міста. Незмінними в містах і селах лишились вічові традиції, де всі найважливіші питання вирішувались на віче, там же обирались і старости. 
Встановлено, що впродовж XI-XII століть відбувалось упровадження двірцево-вотчинної системи управління, яка деякий час співіснувала з десятковою, але згодом цілком її витіснила. Князівській двір перетворився на політичний і адміністративний центр управління державою, не лише на центральному, а й на місцевому рівнях. У великих містах, волостях і погостах двір з усіма посадовцями став типовою моделлю місцевої влади. Усе більшого поширення набувало князівське, боярське та церковне землеволодіння. Виникла вотчинна форма власності, за якою землю можна було відчужувати разом з її населенням, а власник землі також отримував право на здійснення місцевої влади. У XII-XIII століттях Давньоруська держава перетворилась на типову сюзеренно-васальну монархію, а великий князь здійснював управління на місцях через своїх васалів - місцевих (удільні) князів і бояр.

Ключові слова: Давньоруська держава, Русь, Київська Русь, органи місцевої влади, посадник, князівський двір, місцеве самоврядування, громада.

\section{Summary}

Karpichkov V.O. Formation and development of the local authorities in the Old Rus state. - Article. The article examines the local authorities in the Old Rus state at the end of IX-XIII centuries, their structure and features.

It is established that the decimal system did not separate the central government from the local, until the X century the local government was carried out by the voivodes of the prince's druzhyna (retinue) tysatsky, sotsky and desyatsky (thousands, hundreds, tens) who were appointed by the Grand Duke and elected officials - elders (village elders) in the villages. The basis of local self-government consisted of communities of towns and villages and their main body was viche which decided all the most important issues and elders were elected.

After the administrative reforms of the X century the territory of Rus was divided into landsprincipalities with their own devison into volosts (districts) and pogosts (churchyards). During that time the management in large cities was carried out by the mayors of the Grand Duke - princely sons, muji (authorized prince's people), local princes and princes-leaders, volostels in volosts, governors of the prince in pogosts (churchyards) also elected officials - tysatsky and sotsky in cities and elders in villages. At that time, the state was a multilevel system of territorial communities in which one can distinguish the communities of the older city, the communities of its subordinate younger cities (suburbs) and rural communities (vervi). The self-government of the community of the older city, smaller cities and volost were inseparable, but the main bearer of power was the community of the older city. The viche traditions remained unchanged in towns and villages where all the most important issues were decided by the viche and elders were also elected there.

It is established that during the XI-XII centuries the palace-patrimonial system of government was introduced which for some time coexisted with the decimal system, but later completely supplanted it. The prince's palace became a political and administrative center of government not only at the central but also at the local level. In large cities, volosts and pogosts, the palace with all officials has become a typical model of local authority. Princely, boyar and church land ownership became more and more widespread. There was a patrimonial form of ownership, according to which the land could be alienated together with its population and the owner of the land also received the right to exercise the local authority. From the XII-XIII centuries the Old Rus state became a typical suzerain-vassal monarchy and the Grand Duke ruled on the spot through his vassals - local (udylniy) princes and boyars.

Key words: Old Rus state, Rus, Kievan Rus, local authorities, mayor, prince's palace, local selfgovernment, community. 